\title{
RANCANG BANGUN APLIKASI SISTEM PENGOLAHAN DATA PEMBUATAN AKTA TANAH PADA KANTOR DESA CANGKUDU TANGERANG
}

\author{
Sri Rahayu ${ }^{1}$ \\ Sandro Alfeno ${ }^{2}$ \\ Kartika Novianti Wahyono ${ }^{3}$ \\ Dosen AMIK Raharja Informatika ${ }^{1}$, Dosen STMIK Raharja ${ }^{2}$, Mahasiswa STMIK Raharja \\ Teknik Informatika ${ }^{3}$ \\ e-mail: $\underline{\text { srirahayu@ @aharja.info }}{ }^{1}$, ${\text { sandro@ } \text { raharja.info }^{2}}^{2} \underline{\text { kartika.novianti@ raharja.info }}^{3}$
}

\begin{abstract}
ABSTRAKSI
Suatu instansi dalam pemerintahan tidak akan pernah luput dari perkembangan ilmu pengetahuan dan teknologi terutama perkembangan yang terjadi pada teknologi komputer yang bermanfaat dalam menyelesaikan masalah-masalah pemerintahan, khususnya pemerintah daerah Desa Cangkudu dalam melayani pembuatan surat permohonan pembuatan akta tanah. Dalam pengolahan data pemohon akta tanah masih belum mempunyai sistem yang efektif dan efisien, sehingga menimbulkan kendala pada penyajian surat, proses pencarian dokumen permohonan akta tanah yang sudah lama dibuat membutuhkan waktu yang lama harus mencari data-datanya pada file yang tersimpan, serta penyajian laporan yang belum otomatis. Oleh karena itu, penulis merancang aplikasi sistem yang dapat membantu sekretaris desa dalam melakukan pengolahan data sehingga proses pendataan menjadi lebih cepat. Proses pencarian data pemohon pembuatan akta tanah yang telah lama dibuat menjadi lebih cepat. Serta penyusunan laporan menjadi lebih efisien.
\end{abstract}

Kata Kunci: Sistem, Akta Tanah, Laporan

\section{ABSTRACT}

An institution in the government will never escape the development of science and technology, especially the developments that occur in computer technology that are useful in solving the problems of government, especially the local government of Cangkudu Village in serving the making of applications for making land certificates. In the data processing the applicant's land deed still does not have an effective and efficient system, thus creating constraints on the presentation of the letter, the process of finding a land certificate application document that has long been made requires a long time to find the data in the stored file, as well as the presentation of the not yet automatic. Therefore, the author designs a proposal system application that can help the village secretary to do data processing so that the data collection process becomes faster. The data search process for applicants making land certificates has long been made faster. As well as preparing reports to be more efficient.

Keywords: System, Land Deed, Report

\section{PENDAHULUAN}

Suatu instansi dalam pemerintahan tidak akan pernah luput dari perkembangan ilmu pengetahuan dan teknologi terutama perkembangan yang terjadi pada teknologi komputer yang bermanfaat dalam menyelesaikan masalah-masalah pemerintahan, khususnya pemerintah daerah Desa Cangkudu dalam melayani pembuatan surat permohonan pembuatan akta tanah. 
Saat ini pada Kantor Desa Cangkudu, proses pengolahan data surat permohonan pembuatan akta tanah dilakukan secara manual. Dalam pengolahan data pemohon akta tanah masih belum mempunyai sistem yang efektif dan efisien yaitu masih menggunakan Microsoft Word, sehingga menimbulkan kendala pada penyajian surat, proses pencarian dokumen permohonan akta tanah yang sudah lama dibuat membutuhkan waktu yang lama harus mencari data-datanya pada file yang tersimpan, serta penyajian laporan yang belum otomatis. Hal tersebut kuran membantu pekerjaan sekretaris desa dalam proses pengolahan data pemohon pembuatan akta tanah pada kantor Desa Cangkudu.

Berdasarkan berbagai permasalahan yang terjadi di atas maka dibuatlah sebuah sistem informasi yang memudahkan sekretaris desa dalam mengolah data-data pemohon pembuatan akta tanah. Sistem ini bertujuan untuk memberi keefektifan dan efisiensi proses pengolahan data pemohon akta tanah, pencarian data pembuatan akta tanah, dan pembuatan laporan pembuatan akta tanah.

\section{PERMASALAHAN}

Setelah dilakukan analisa oleh penulis, ditemukan beberapa masalah yang dapat diatasi dengan terciptanya suatu sistem pengolahan data yang baik. Proses pencarian data pemohon pembuatan akta tanah yang telah lama dibuat memerlukan waktu yang lama, serta penyajian laporan yang masih manual sehingga belum menghasilkan laporan yang bersifat otomatis. Permasalahan yang yang terdapat pada sistem pengolahan data yang berjalan saat ini di Kantor Desa Cangkudu yaitu proses pengolahan data pemohon pembuatan akta tanah masih semi-komputerisasi menggunakan Microsoft Word, sedangkan pengajuan pemohon cukup banyak dan data yang dibuat untuk diproses juga banyak. Belum ada fasilitas data integrated pada penggunaan sistem yang lama, seperti yang tergambar pada Gambar 1 dibawah.

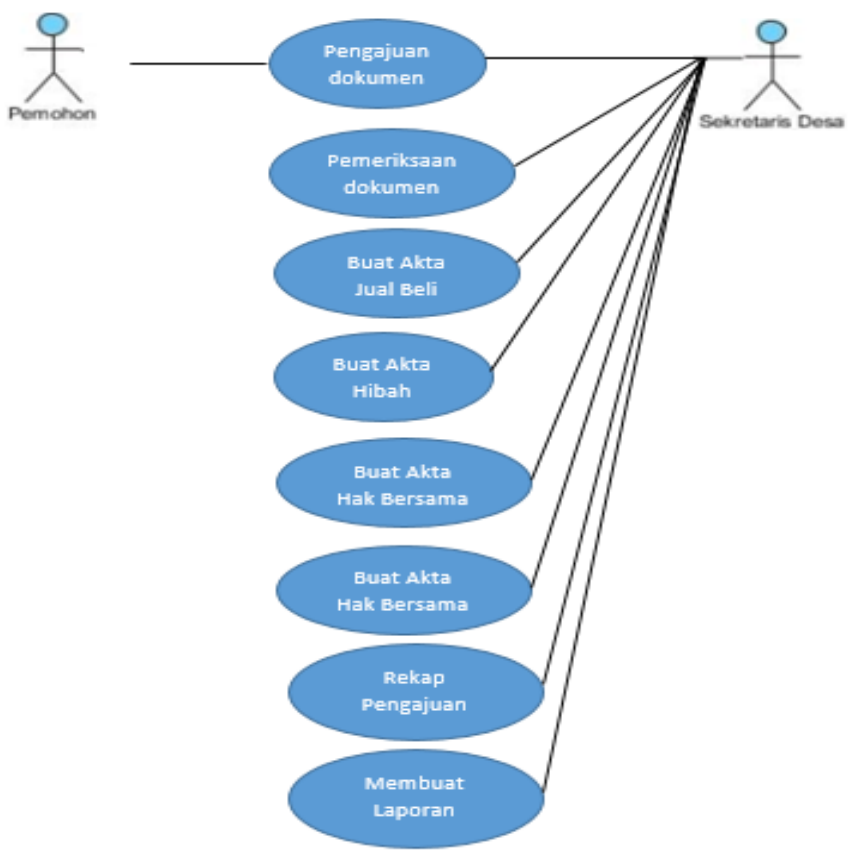

Gambar 1. Use case diagram Sistem Lama

\section{TINJAUAN PUSTAKA}

\section{Definisi Sistem}

Sistem adalah suatu jaringan kerja dari prosedur-prosedur yang saling berhubungan, berkumpul bersama-sama untuk melakukan kegiatan atau untuk melakukan sasaran-sasaran tertentu. [1] 


\section{Definisi Data}

Data adalah fakta-fakta yang menggambarkan suatu kejadian yang sebenarnya pada waktu tertentu. [2]

\section{Definisi Unified Modelling Language (UML)}

Unified Modeling Language (UML) merupakan kumpulan dari struktur dan teknik untuk pemodelan desain program berorientasi objek (OOP) beserta aplikasinya. UML adalah suatu metode untuk mengembangkan sistem OOP dan sekelompok perangkat tool untuk mendukung pengembangan sistem tersebut.[3]

\section{Konsep Dasar Akta PPAT}

Akta PPAT merupakan salah satu sumber data bagi pemeliharaan data pendaftaran tanah, maka wajib dibuat sedemikian rupa sehingga dapat dijadikan dasar yang kuat untuk pendaftaran pemindahan dan pembebanan hak yang bersangkutan. [4]

\section{METODOLOGI PENELITIAN}

Metode Analisa Sistem

Penulis menggunakan metode analisa SWOT (Strength Weakness Opportunities Threats) sebagai metode analisa sistem. Metode analisa SWOT dimanfaatkan untuk meminitor kondisi lingkungan kantor Desa Cangkudu baik secara internal maupun eksternal sebagai parameter untuk dapat menilai kekuatan, kelemahan, peluang, dan ancaman yang ada pada kantor Desa Cangkudu, sehingga dapat mendukung proses pengambilan keputusan.

Metode Perancangan Sistem

Penulis menggunakan metode rancangan berbasis obyek dengan tahapan UML (Unified Modelling Language) yaitu use case, sequence, dan class diagram sebagain metode perancangan sistem. Program yang digunakan untuk membuat UML yaitu Visual Paradigm 13.2.

\section{PEMBAHASAN}

Pada penelitian ini, penulis akan menjelaskan mengenai sistem pengolahan data pemohon pembuatan akta tanah yang berjalan saat ini pada Kantor Desa Cangkudu yang masih dikerjakan secara semikomputerisasi dengan menggunakan Microsoft Word. Proses pengolahan data yang masih bersifat semi-komputerisasi membuat pendokumentasian data menjadi kurang efektif. Penyusunan kembali laporan masih manual sehingga belum menghasilkan laporan yang otomatis. Oleh karena itu, dibutuhkan sistem yang dapat menangani masalah-masalah tersebut.

Penulis merancang sistem usulan yang dapat membantu sekretaris desa dalam melakukan pengolahan data sehingga proses pendataan menjadi lebih cepat. Proses pencarian data pemohon pembuatan akta tanah yang telah lama dibuat menjadi lebih cepat. Serta penyusunan laporan menjadi lebih efisien. Pada sistem yang diusulkan, proses pengipuntan data pemohon akta tanah hanya memasukkan nomor NIK pemohon pada sistem dan secara otomatis data pemohon akan terdaftar pada tabel pemohon akta tanah. Pada penulisan jurnal ilmiah ini, ruang lingkup penelitian hanya pada beberapa poin berikut, yaitu:

- Perancangan sistem pengolahan data pemohon pembuatan akta tanah berbasis web pada Kantor Desa Cangkudu Kecamatan Balaraja Kabupaten Tangerang

- Proses pencarian data yang telah lama dibuat dapat secara cepat dikerjakan.

- Proses penyusunan laporan yang menjadi lebih mudah dan otomatis.

\section{LITERATURE REVIEW}

Menurut Hermawan dalam Rahardja dkk (2016:24), menerangkan bahwa "Literature review adalah bahan yang tertulis berupa buku, jurnal yang membahas tentang topik yang hendak diteliti”.[5]

Sudah banyak penelitian yang membahas tentang sistem pengolahan data yang bemanfaat dalam instansi pemerintahan. Dalam upaya pengembangan dan penyempurnaan sistem pengolahan data 
pemohon akta tanah maka diperlukan studi pustaka yang merupakan salah satu metode penelitian yang akan dilakukan. Beberapa literature review yang berhubungan dengan penelitian yang akan dilakukan, yaitu sebagai berikut:

1. Penelitian yang dilakukan oleh Indah Beatry, Feysilya Lusi, dan Justinus Andjarwirawan pada tahun 2017 dari Universitas Kristen Petra Surabaya yang berjudul "Aplikasi Sistem Informasi Pertanahan Berbasis Website Pada Kantor Pertanahan Kabupaten Kupang Provinsi NTT". Penelitian ini membahas tentang aplikasi yang dapat membantu dalam pengisian formulir pendaftaran, dan dapat menerima informasi tentang status proses pengurusan sertifikat tanah melalui website dan SMS. Aplikasi ini diharapkan dapat membantu staff dikantor BPN Kabupaten Kupang untuk melayani pemohon dalam mendapatkan informasi mengenai pengurusan sertifikat tanah.[6]

2. Penelitian yang dilakukan oleh Gilang Pratama, Erwin Gunadhi, dan Nahdi Hadiyanto pada tahun 2014 dari Sekolah Tinggi Teknologi Garut yang berjudul "Perancangan Program Aplikasi Pengelolaan Biaya Pembuatan Akta Jual Beli Tanah Di Kantor Kecamatan Leles". Permasalahan yang terjadi dalam pembuatan akta jual beli tanah di Kecamatan Leles, petugas mengalami kesulitan dalam menetukan biaya yang harus dibayarkan, ditambah dengan biaya-biaya lain yang kurang jelas sehingga proses pembayaran menjadi tidak transparan. Berdasarkan permasalahan yang ada, maka dibangun sistem yang mempermudah petugas dalam pengelolaan biaya akta jual beli tanah, serta mempermudah penyimpanan data sehingga tidak menghabiskan tempat.[7]

3. Penelitian yang dilakukan oleh Dedi dan Hardi Yusmanto pada tahun 2013 dari STMIK Bina Sarana Global yang berjudul "Rancang Bangun Sistem Informasi Administrasi Akta Jual Beli Berbasis Web (Studi Kasus di Notaris dan PPAT Andriyani, SH., M.Kn)". Permasalahan dalam transaksi jual beli pada di Kantor NOTARIS/PPAT ANDRIYANI MIRAWATI, SH. M.kn. proses penyampaian informasi untuk klien masih dilakukan secara manual dan mencari berkas. Dari permasalahan yang terjadi, maka dibangun sistem informasi administrasi berbasis web yang dapat mempermudah pengguna dalam mendapatkan informasi, sehingga membantu tercapainya hasil kerja yang maksimal, serta dapat memberikan informasi yang cepat dan akurat. Sistem ini dibangun menggunakan bahasa pemrograman PHP dan database MySQL.[8]

4. Penelitian yang dilakukan oleh Dany Indah Pertiwi dan F.X Wisnu Yudo Untoro pada tahun 2015 dari Universitas Wijaya Kusuma Surabaya yang berjudul "Sistem Informasi Kepemilikan Tanah Berbasis Web". Penelitian ini membahas mengenai sistem kepemilikan tanah. Pada penelitian ini, penulis membangun sistem informasi kepemilikan tanah berbasis web sehingga memberi keuntungan berbagai pihak. Sistem yang dibangun menggunakan bahasa pemrograman PHP dan database MySQL. Kelebihan dari sistem ini, yaitu mempermudah dalam pencarian informasi kepemilikan tanah hanya dengan menginput nomor NIK atau nomor sertifikat yang akan dicari.[9]

\section{PEMECAHAN MASALAH}

Dalam membangun suatu sistem dibutuhkan rancangan diagram yang memudahkan untuk membuat rancangan suatu sistem supaya sistem yang dibangun lebih terstruktur. Dalam perancangan sistem pengolahan data pemohon pembuatan akta tanah berbasis web dibuat menggunakan tools Microsoft Visual Paradigm 13.2.

\section{- Sequence Diagram}

Sequence Diagram ini digunakan untuk menggambarkan apa saja objek yang digunakan terkait aplikasi yang akan dibangun dalam sistem, begitu pula keterkaitan antar objek. Hal ini penting agar rancangan aplikasi yang dibangun sesuai dengan hasil rancangan yang terdokumentasi dengan baik. 
ISSN : $2356-5195$

Online ISSN: 2654 - 8704

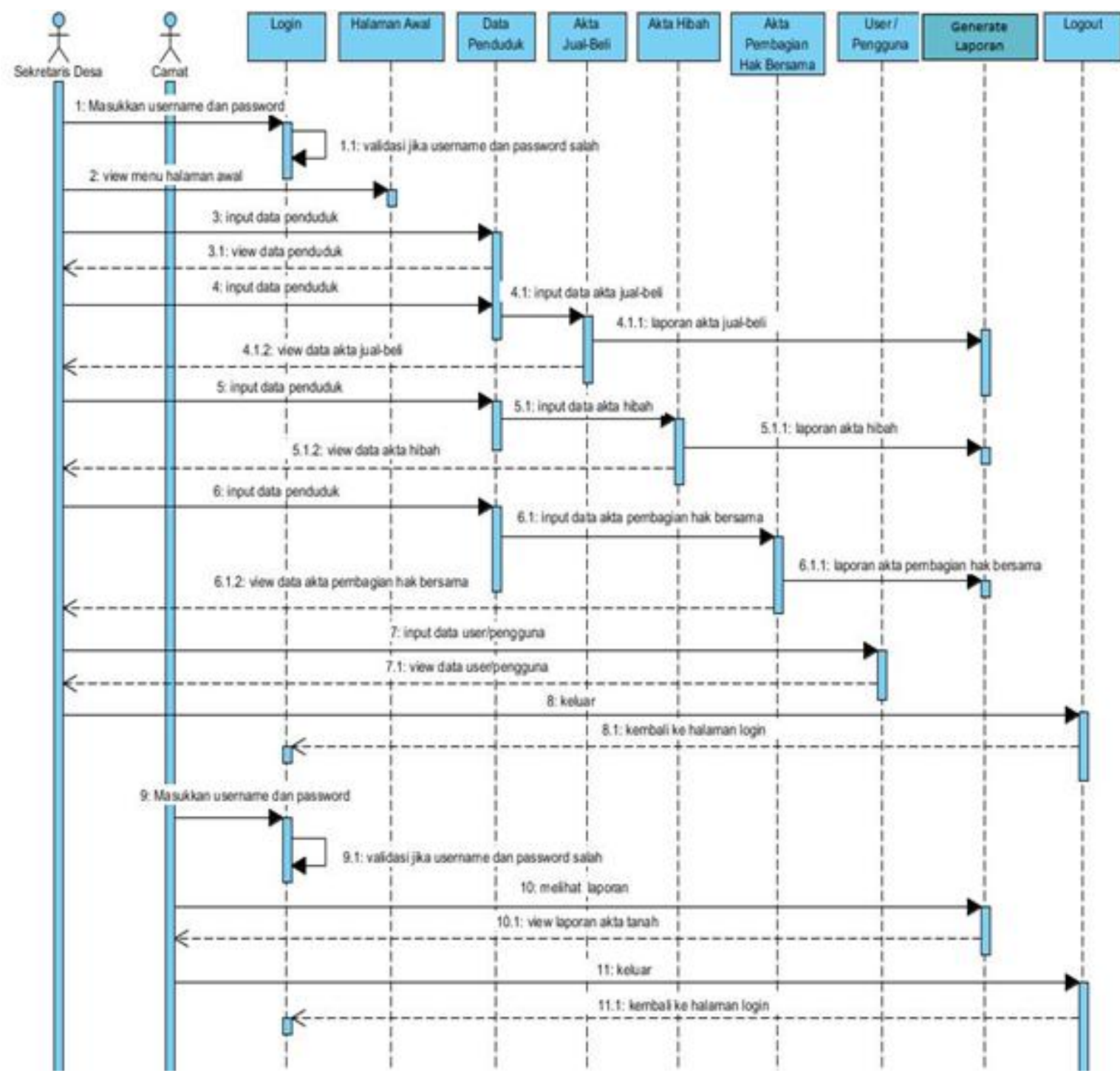

Gambar 2. Sequence Diagram Sistem Pengolahan Data Pembuatan Akta Tanah

Berdasarkan Gambar 2 diatas terdapat objek data penduduk yang merupakan objek yang digunakan untuk merancang kelas objek data penduduk. Objek tersebut akan berfungsi untuk menggambarkan pada halaman aplikasi, terdapat master data Nomor Induk Kependudukan (NIK) yang dapat mempermudah admin dalam menginput pengajuan pembuatan akta jual beli tanah. Sedangkan untuk beberapa form terkait dengan pengajuan penduduk meliputi objek Akta Jual Beli, objek Akta Hibah, serta objek Akta Pembagian Hak Bersama.

\section{- Class Diagram}

Pada Gambar 3 dibawah ini merupakan rancangan basis data yang digunakan dalam sistem pengolahan data pembuatan akta tanah. 


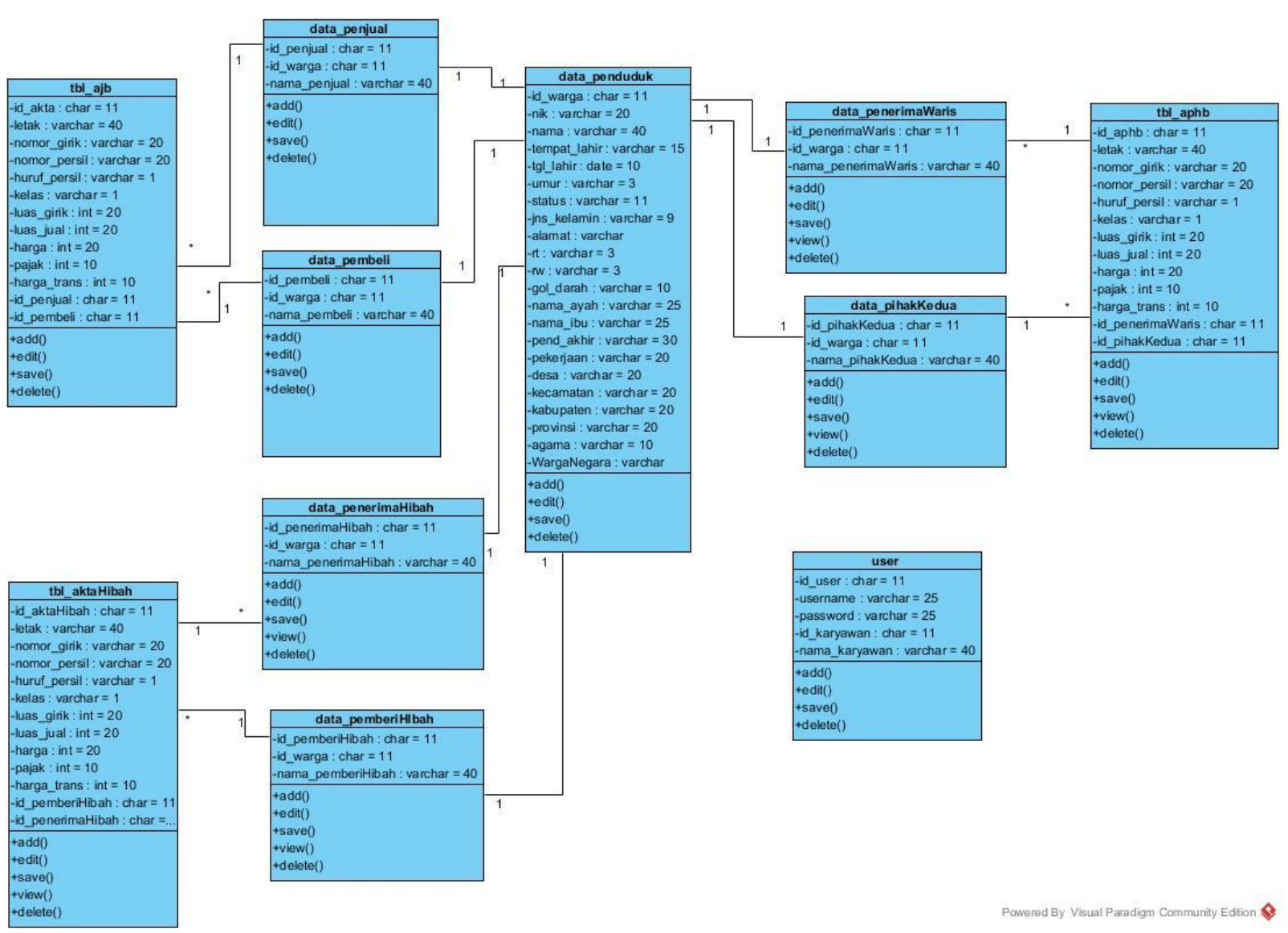

Gambar 3. Class Diagram Sistem Pengolahan Data Pembuatan Akta Tanah

\section{RANCANGAN IMPLEMENTASI}

\section{Tampilan Aplikasi}

\section{Form Pendaftaran Akta Jual-Beli}

Pada tampilan Gambar 4 dibawah ini adalah tentang input data yang berkaitan dengan data pemohon pembuatan akta jual-beli tanah.

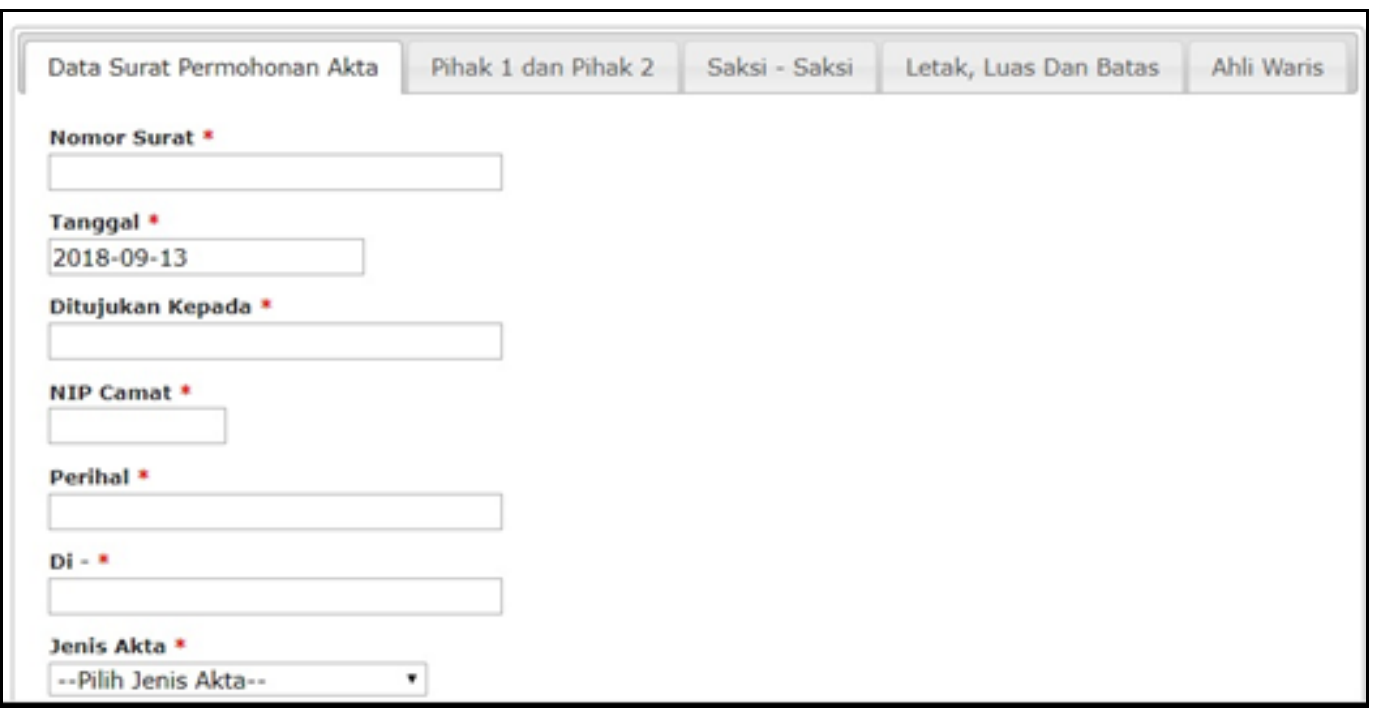

Gambar 4. Menu Form Pendaftaran Akta Jual-Beli 


\section{Form Input Data Pihak 1 dan Pihak 2 Akta Jual Beli}

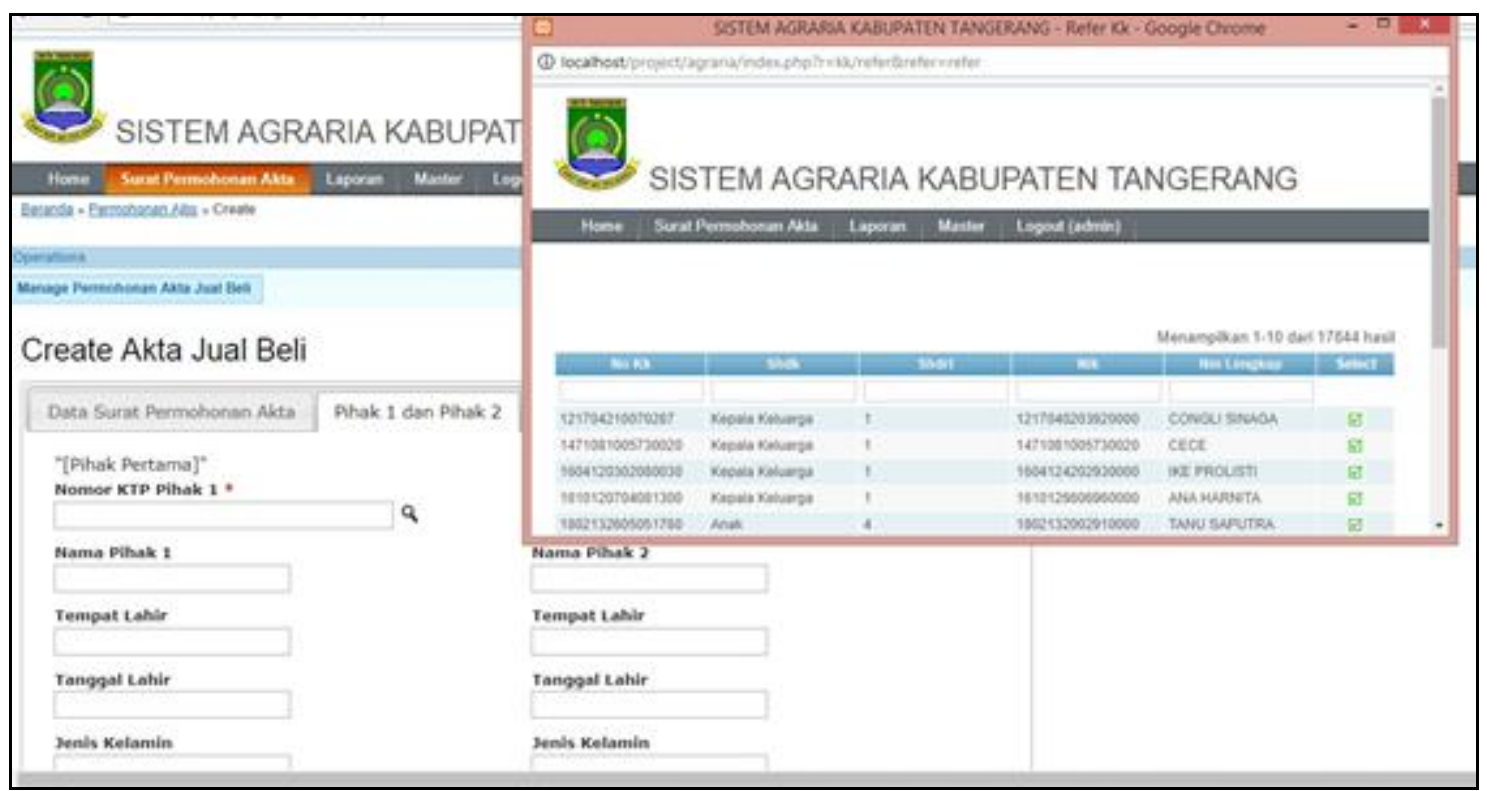

Gambar 5. Form Input Data Pihak 1 dan Pihak 2 Akta Jual Beli

Pada gambar 5 diatas, pengisian data Pihak 1 dan Pihak 2 pada akta jual beli terdapat item pengisian NIK, pengisian tersebut difasilitasi berupa data master yaitu data penduduk yang berisi NIK yang terdaftar diwilayah tersebut sehingga admin diberikan kemudahan untuk melakukan verifikasi data penduduk. Kemudahan lain adalah saat admin mengisi NIK, semua elemen data yang terkait dengan NIK tersebut akan otomatis terisi, hanya bebera elemen data saja yang perlu ditambahkan.

\section{Form Input Data Saksi 1 dan Saksi 2 Akta Jual Beli}

Pada gambar 6 dibawah ini juga demikian, pengisian data para saksi pada akta jual beli terdapat item pengisian NIK, pengisian tersebut juga difasilitasi berupa data master NIK, semua elemen data yang terkait dengan NIK tersebut akan otomatis terisi, hanya beberapa elemen data terkait saksi saja yang perlu ditambahkan.

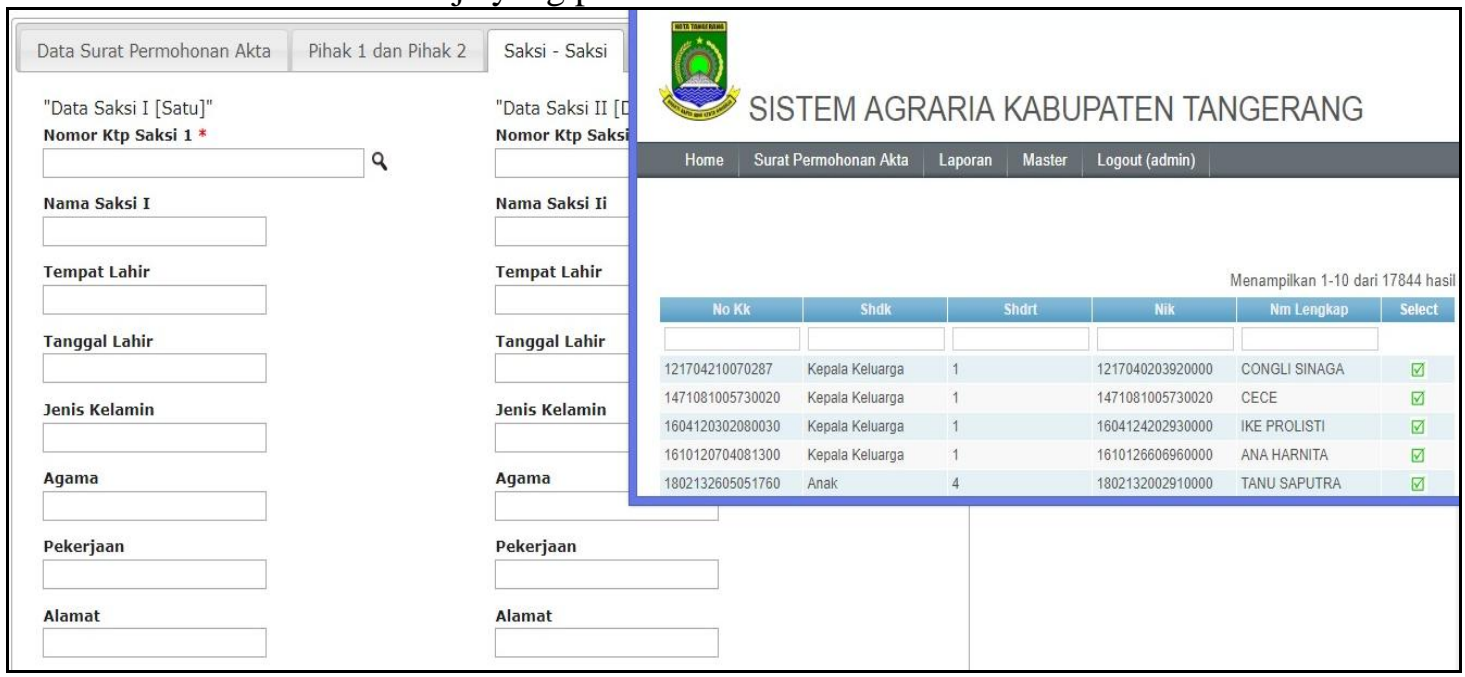

Gambar 6. Form Input Data Saksi 1 dan Saksi 2 Akta Jual Beli 


\section{Form Input Data Luas, Letak dan Batas Tanah}

Form penting lainnya yang perlu disediakan dalam pembuatan akta tanah ini adalah form yang digunakan terkait data tanah. Antara lain untuk pengisian luas tanah, letak tanah dan batas tanah, seperti yang tampil pada Gambar 7 dibawah ini.

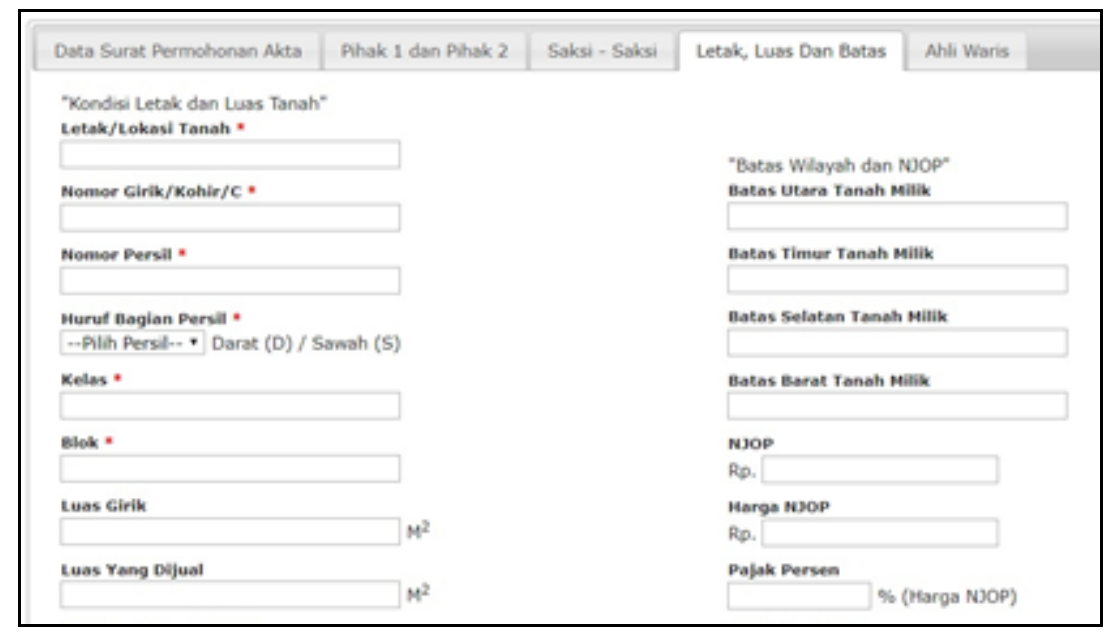

Gambar 7. Form Input Data Luas, Letak dan Batas Tanah

\section{Form Input Data Ahli Waris}

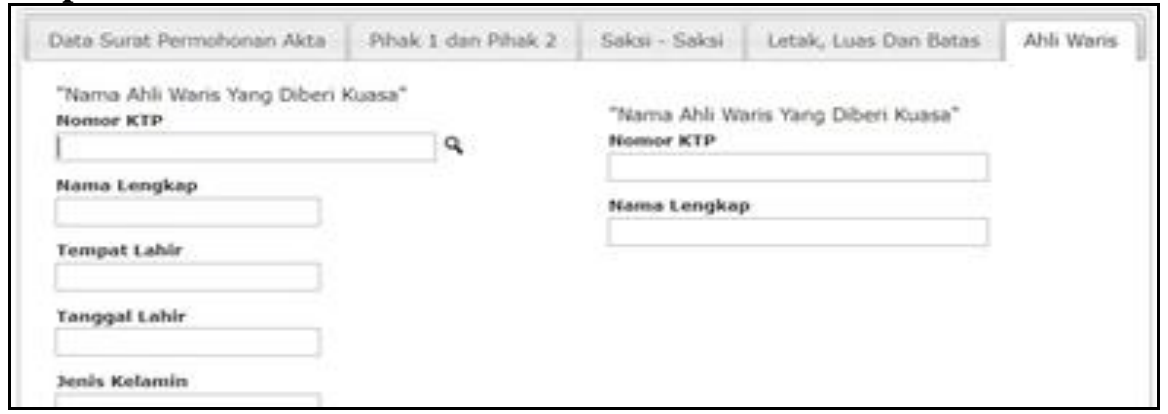

Gambar 8. Form Input Data Ahli Waris

Form isian penting terakhir adalah form Input Data Ahli Waris yang berfungsi untuk mengisi data terkait ahli waris, seperti yang terlihat pada Gambar 8 diatas.

\section{Tampilan Surat Permohonan Akta Jual Beli}

Gambar 9 dan 10 dibawah ini adalah contoh display hasil dari pengolahan data pembuatan akta tanah yang telah diisi pada form mulai dari Gambar 4 sampai dengan Gambar 8. 


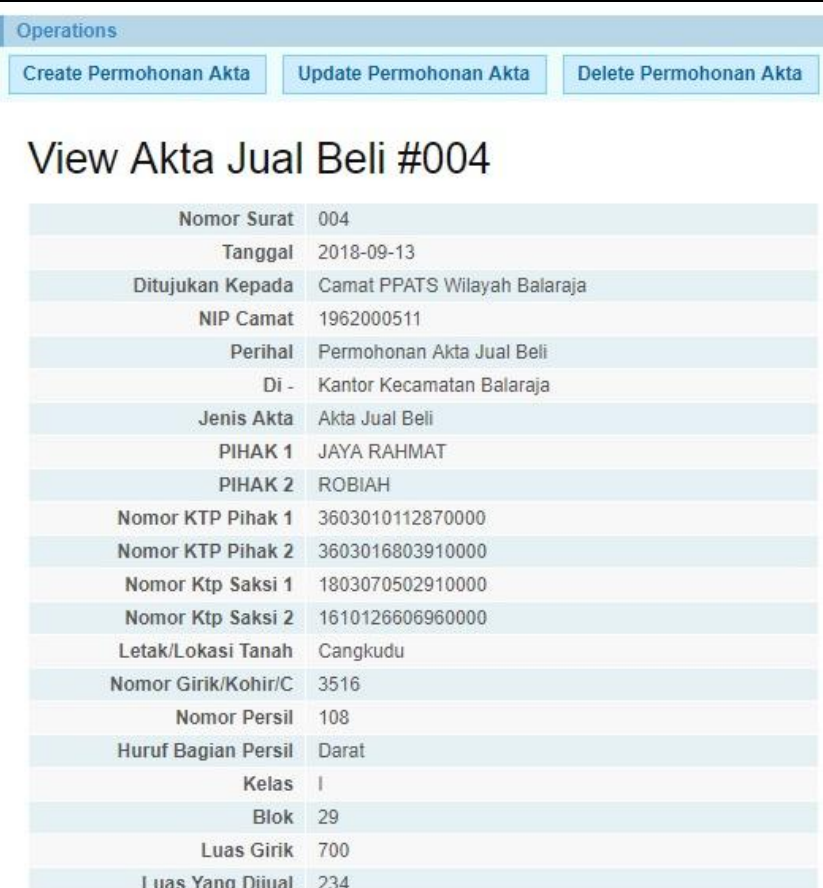

Gambar 9. View Surat Permohonan_1

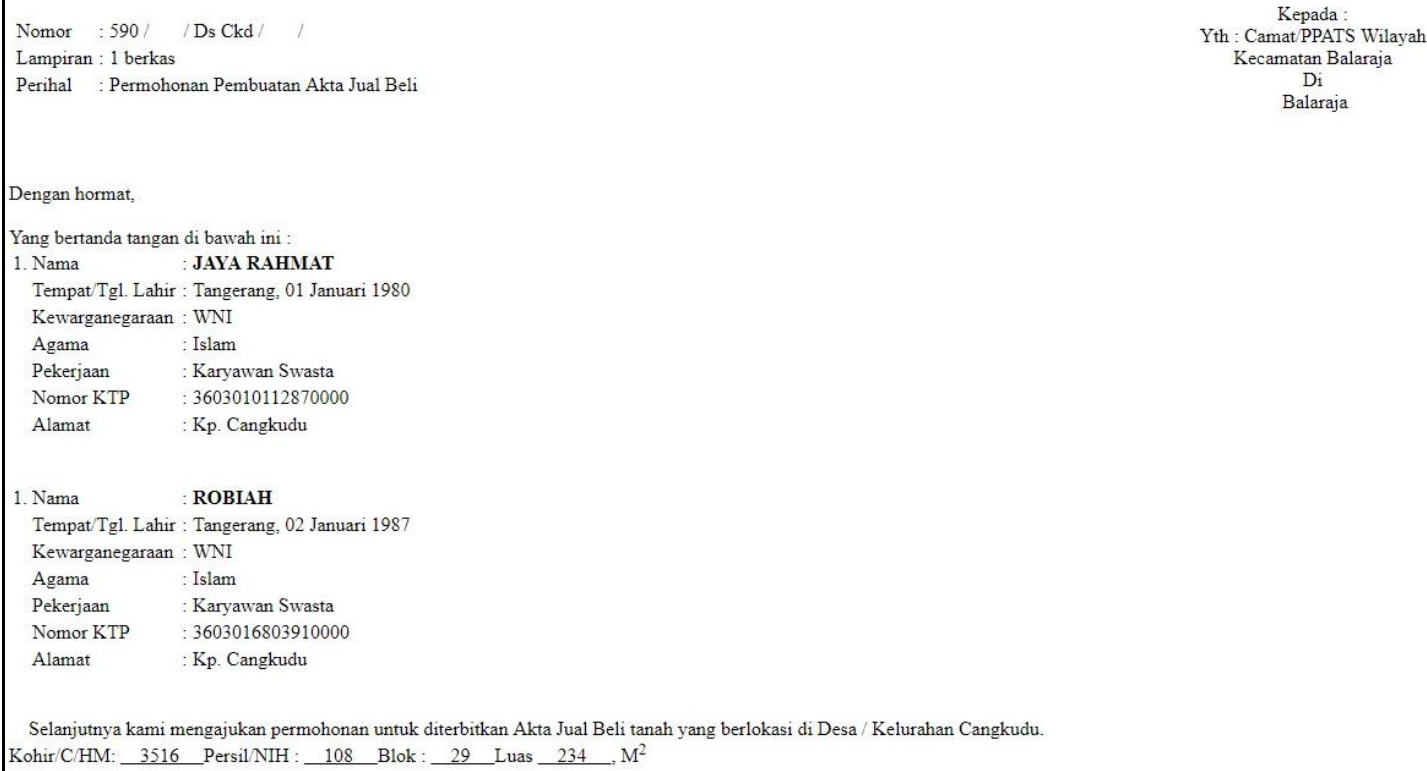

Gambar 10. View Surat Permohonan_2

Database telah mengintegrasikan isian data pada form mulai dari Gambar 4 sampai dengan Gambar 8, sehingga dapat mempermudah kinerja user (sekretaris desa) dan tampil sesuai kebutuhan. Tampilan Gambar 10 yang selanjutnya akan diserahkan pada pihak Kecamatan untuk persetujuan pembuatan akta tanah. Selain itu, tersedia juga halaman yang mempermudah user atau admin dalam pencarian informasi surat pengajuan yang pernah dibuat, seperti yang tampil pada Gambar 11 dibawah ini. 


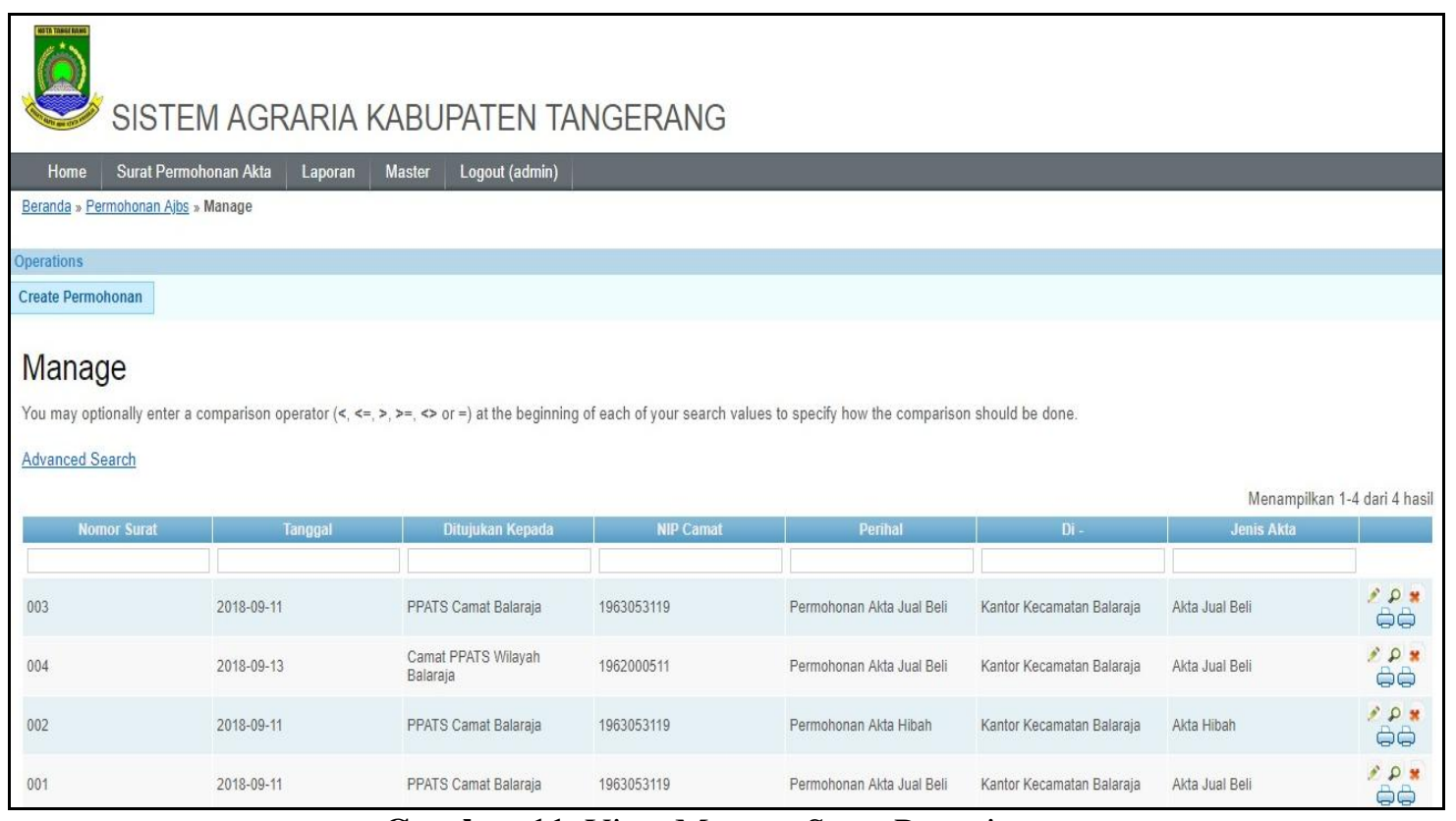

Gambar 11. View Manage Surat Pengajuan

7. Tampilan Laporan Data Pemohon Akta Jual Beli

Gambar 12 Dibawah ini adalah hasil laporan yang secara otomatis tampil dari hasil keseluruhan pengajuan yang pernah dibuat.

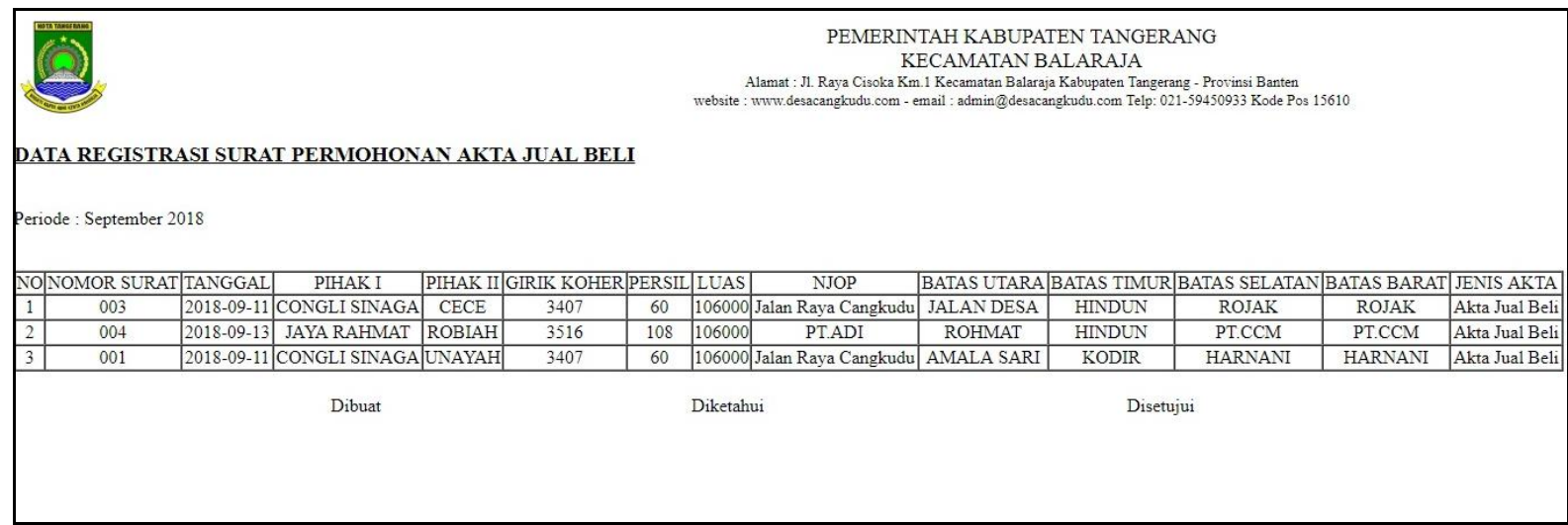

Gambar 12. Laporan Pemohon Akta Jual Beli

\section{KESIMPULAN}

Setelah dianalisis pada sistem pengolahan data pemohon pembuatan akta tanah yang berjalan saat ini pada Kantor Desa Cangkudu masih bersifat semi-komputerisasi sehingga membutuhkan waktu yang tidak sedikit dalam pengolahan datanya. Pada rancang bangun aplikasi sistem pengolahan data pemohon akta tanah yang dibuat ini, dihasilkan sebuah aplikasi yang dapat membantu permasalahan yang dihadapi Kantor Desa Cangkudu mulai dari input keseluruhan form yang dibutuhkan, pencarian informasi akta tanah, sampai dengan laporan tentang data pemohon pembuatan akta tanah, sehingga memudahkan sekretaris desa dalam penginputan data sampai pelaporan dengan cepat.

\section{DAFTAR PUSTAKA}

[1] Hutahaean, Jeperson. 2014. Konsep Sistem Informasi. Yogyakarta: Deepublish

[2] Lubis, Adyanata. 2016. Basis Data Dasar. Yogyakarta: Deepublish 
[3] Warsito, Ary Budi, Muhamad Yusup dan Moh. Iqbal Awi Makaram. 2015. Perancangan SIS+ Menggunakan Metode YII Framework pada Perguruan Tinggi Raharja. Tangerang: Jurnal CCIT. Vol.8, No.2: 24-33

[4] Istanti dan Akhmad Khisni. 2017. Akibat Hukum Dari Akta Jual Beli Tanah Dihadapan PPAT Yang Dibuat Tidak Sesuai Dengan Prosedur Pembuatan Akta PPAT. Semarang: Jurnal AktaVol.4 No.2: 271-282

[5] Rahardja, Untung, Khanna Tiara dan Ria Utami. 2016. Optimalisasi Penerapan Rooster Berbasis Osticket Untuk Meningkatkan Mutu Pelayanan. Tangerang: Technomedia Journal. Vol.1, No.1: 20-35

[6] Beatry, Indah, Feysilya Lusi, dan Justinus Andjarwirawan. 2017. Aplikasi Sistem Informasi Pertanahan Berbasis Website Pada Kantor Pertanahan Kabupaten Kupang Provinsi NTT. Surabaya: Jurnal Infra Vol. 5, No.2

[7] Pratama, Gilang, Erwin Gunadhi, dan Nahdi Hadiyanto. 2014. Perancangan Program Aplikasi Pengelolaan Biaya Pembuatan Akta Jual Beli Tanah Di Kantor Kecamatan Leles. Garut: Jurnal Algoritma, Vol. 11, No.1

[8] Dedi dan Hardi Yusmanto. 2013. Rancang Bangun Sistem Informasi Administrasi Akta Jual Beli Berbasis Web (Studi Kasus di Notaris dan PPAT Andriyani, SH., M.Kn). Tangerang: Jurnal Sisfotek Global, Vol.3, No. 2: 1-5

[9] Pertiwi, Dany Indah dan F.X Wisnu Yudo Untoro. 2015. Sistem Informasi Kepemilikan Tanah Berbasis Web. Surabaya: Information Technology Journal, Vol.1, No.1: 33-44 